\title{
KALICZKA Nándor
}

\section{A TECHNOLÓGIAI FEJLŐDÉS HATÁSA A TARTÓS ESZKÖZÖK GAZDASÁGI ÉRTÉKCSÖKKENÉSÉRE}

A cikk a tartós eszközök gazdasági értékcsökkenésének elméleti hátterét vizsgálja az eszközökben megtestesülő szolgálatok felemésztôdése szempontjából. Ezt a felemésztôdést az eszközök kimerülésén és elhasználódásán túl, a gazdasági környezetben megjelenố testet öltố és testet nem öltő technológiai fejlôdés következtében fellépô avulás is befolyásolja, mely avulás hatását a cikk részletesen tárgyalja. A technológiai fejlódés következtében fellépó avulásnak igen fontos szerepe van az eszközökhöz, és azok használati módjához legjobban illeszkedő értékcsökkenési minta kirajzolásában, amely alapján meghatározott értékcsökkenés központi eleme a vállalkozások jövedelmének, valamint a vállalkozási output egységköltségének, ami az output árazásának fontos tényezôje. Ezáltal az értékcsökkenés meghatározásánál figyelembe vett avulás hatással van a vállalkozás termék és tớkepiaci versenyképességére.*

Kulcsszavak: értékcsökkenés, technológiai fejlődés, avulás

A vállalatok termelési folyamataik során outputokat állítanak elô, mely előállítás során változatos inputokat használnak fel. Az így felhasznált inputok egy része a vállalkozás által használt tartós eszközök szolgálataiból származik, mely tartós eszközök legfóbb jellemzője, hogy több beszámolási perióduson keresztül szolgálják a vállalkozás múködését. Ezáltal az egyes beszámolási periódusokban szembe kell nézni a tartós eszközök szolgálatainak az outputokhoz való hozzárendelésének problémájával, mely hozzárendelésben a tartós eszközök felemésztődésének ${ }^{l}$ megragadása igen fontos szerephez jut. Ennek a felemésztôdésnek egy meghatározott része az értékcsökkenés. A tartós eszközök értékcsökkenésének pontos megragadása a vállalkozás számára egyrészt azért fontos, mert a felosztott értékcsökkenés része az output egységköltségének, ezáltal az output árazása révén hatással van az output versenyképességén keresztül magára a vállalkozás termékpiaci versenyképességére, másrészt a tartós eszközök értékcsökkenése része a vállalkozás jövedelemszámításának, ahol többek közt a tôke kezdeti értékének megórzését biztosítja. ${ }^{2}$ A vállalkozás jövedelme azonban a vállalkozás teljesítményének egy igen fontos mértéke, ezáltal az értékcsökkenés számításának mikéntje hatással van a vállalkozás tókepiaci versenyképességére is.

Az értékcsökkenés számításának több elméleti közelítése is megjelent a korai szakirodalomban, ${ }^{3}$ azonban a velük kapcsolatban zajló elméleti viták világossá tették, hogy csak a tényleges értékváltozás szemlélet képes az eszköz felemésztődésének megragadásán keresztül a megfeleló vagyon és jövedelemértékeket eredményezni, ${ }^{4}$ mely felismerést elsóként Hotelling fogalmazta meg. Hotelling (1925) szakított az időalapú allokáció felfogással, és az eszköz értékcsökkenésére egy olyan rátaként tekintett, mellyel az eszközök értéke az adott periódus során csökken.

\section{A tartós eszközök értékváltozásának felbon- tása}

Az eszközök értékváltozásának és értékcsökkenésének megkülönböztetésére jelöljük az $s$ éves eszköz értékét a $t$ idôpontban $\mathrm{P}_{\mathrm{t}, \mathrm{I}-\mathrm{e}}^{\mathrm{I}}$. Ekkor az eszköz $\mathrm{P}_{\mathrm{t}, \mathrm{s}}^{\mathrm{I}}$ értékének változása a $t$ idópontról a $t+1$ idôpontra a következóképpen írható fel.

$$
\text { (1) } \Delta \mathrm{P}_{\mathrm{t}, \mathrm{s}}^{\mathrm{I}}=\mathrm{P}_{\mathrm{t}, \mathrm{s}}^{\mathrm{I}}-\mathrm{P}_{\mathrm{t}+1, \mathrm{~s}+1}^{\mathrm{I}}
$$

Az egyenletból látszik, hogy a két értékelés közt eltelt idố miatt az eszköz életkora $s$-ról $s+1$-re nó. Ezáltal az eszköz egy perióduson át való használat következtében feltehetôen kevesebbet ér a periódus végén, mit a periódus elején. Ekkor viszont nemcsak az eszköz válik egy periódussal öregebbé, hanem az eszköz értékelésének idôpontja is megváltozik, mely következtében egyrészt az árarányok eltolódásával kell szembenéznünk, másrészt a két különbözó időpontban valószínúleg eltéró információkkal rendelkezünk mind az eszköz tulajdonságairól, mind pedig a gazdasági környezetról, mely eltéró információk természetesen az esz-

* A tanulmány a TÁMOP-4.2.1/B-09/1/KMR-2010-0005 projekt támogatásával jött létre.

\section{VEZETÉSTUDOMÁNY}


köz értékére is hatással vannak. Azonban a cikkben a jövốre vonatkozó tökéletes informáltságot és bizonyosságot feltételezve az értékelés dátumának változás esetén csak az árak változásából eredő hatásokat vizsgálom. Az eszköz értékváltozásának imént vázolt két fő elemét az értékcsökkenéssel foglalkozó irodalom fő́rama elkülöníti, ${ }^{5}$ mely elkülönítés diszkrét rendszerét Hulten és Wykoff (1981a) egy mátrixszal szemlélteti, amelyben az eszközök $\mathrm{P}_{\mathrm{t}, \mathrm{s}}^{\mathrm{I}}$ értékváltozása szétválik aszerint, hogy az az eszköz korának növekedéséból, vagy az értékelés dátumának (idôpontjának) változásából ered.

1. ábra

Az eszköz értékváltozásának felbontása kor- és dátumhatásra

(Forrás: Hulten - Wykoff (1981a) alapján)

\begin{tabular}{|l|l|l|l|l}
\hline $\boldsymbol{t}=$ & $\boldsymbol{1}$ & $\mathbf{2}$ & $\mathbf{3}$ & $\ldots$ \\
\hline $\boldsymbol{s}=\mathbf{0}$ & $P_{1,0}^{I}$ & $P_{2,0}^{I}$ & $P_{3,0}^{I}$ & $\ldots$ \\
\hline $\boldsymbol{1}$ & $P_{1,1}^{I}$ & $P_{2,1}^{I}$ & $P_{3,1}^{I}$ & $\ldots$ \\
\hline $\mathbf{2}$ & $P_{1,2}^{I}$ & $P_{2,2}^{I}$ & $P_{3,2}^{I}$ & $\ldots$ \\
\hline $\mathbf{3}$ & $P_{13}^{I}$ & $P_{2,3}^{I}$ & $P_{3,3}^{I}$ & $\ldots$ \\
\hline $\boldsymbol{\cdots}$ & $\ldots$ & $\ldots$ & $\ldots$ & $\ldots$ \\
\hline
\end{tabular}

Az 1. ábrán látható, hogy az (1)-es egyenletben meghatározott értékváltozás a mátrixban egy jobb oldali irányú átlós elmozdulás két cellájának különbségeként értelmezhető, mely értékváltozást Hill (1999) idôsor-értékcsökkenésnek nevez. ${ }^{6}$ Ez az átlós elmozdulás a mátrixban az eszköz korának, valamint az értékelés dátumának együttes megváltozásából ered, mely hatásokat korhatásnak és dátumhatásnak ${ }^{7}$ nevezzük. Ekkor az (1)-es egyenletben meghatározott értékváltozás kor és dátumhatásának diszkrét elkülönítését a következóképpen írhatjuk fel.

$$
\text { (2) } \begin{aligned}
\Delta P_{t, s}^{I}=\left[P_{t+1, s}^{I}-P_{t+1, s+1}^{I}\right]+ \\
{\left[P_{t, s+1}^{I}-P_{t+1, s+1}^{I}\right]=D_{t, s}+G_{t, s+1} }
\end{aligned}
$$

Ahol a $t$ idôpontban az eszköz $s$ korának növekedéséból fakadó értékváltozást, azaz a korhatást $D_{t, s+1}$ jelöli, míg az $s$ korú eszköz értékelési $t$ dátumának megváltozásából eredô értékváltozását, azaz a dátumhatás $G_{t, s+l}$ jelöli. Az értékelés idôpontjának megváltozásából fakadó értékváltozás azon részét, amely az árak változásából ered átértékelési hatásnak neveznek az irodalomban. ${ }^{8}$ Ezzel szemben a korhatást magában foglaló $D_{t, s}$ kifejezés, amely egy $t$ idôpontban fejezi ki egy $s$ és $s+l$ korú eszközök értékei közti különbséget Hulten és Wykoff (1996) (közgazdasági) értékcsökkenésnek, míg Hill (1999) keresztmetszeti értékcsökkenésnek nevez. ${ }^{9} \mathrm{Az}$ idősor-, valamint a keresztmetszeti értékcsökkenés az árak stabilitása esetén azonos, (Diewert, 2005) viszont a keresztmetszeti értékcsökkenés árváltozás esetén is egy viszonylag jól tervezhetố állandó része az eszköz értékváltozásának. A $D_{t, s}$ keresztmetszeti értékcsökkenést gyakran $\delta_{t, s}$ keresztmetszeti értékcsökkenési rátával fejezik ki a szakirodalomban, melyet a következóképpen határozhatunk meg.

$$
\text { (3) } \delta_{t, s}=1-\left(P_{t, s+1}^{I} / P_{t, s}^{I}\right) \text {; ahol } P_{t, s}^{I} \neq 0
$$

\section{Az értékcsökkenés számításának elméleti hát-} tere

Az eszközök értékelésével foglalkozó szakirodalom fóáramában az eszközt gyakran a benne lévô potenciális jövőbeni szolgálatok tárházaként tekintik, mely szolgálatok a vállalkozás múködése során hasznosulnak. ${ }^{10} \mathrm{Ez}$ a felismerés Böhm-Bawerk (1891) (idézi Diewert - Wykoff, 2006) elméleti munkájában már igen korán megjelent. Böhm-Bawerk az eszköz jövő́beni szolgálatainak áramát (flow) kapcsolta össze az eszköz jelenlegi állományával (stock), és az eszköz értékét a belôle származó jövőbeni szolgálatértékek diszkontált jelenértékeként határozta meg. A kapcsolódó szakirodalomban az eszköz egy periódusra vonatkozó szolgálatértékét az eszközök hatékony bérleti piacán kialakult elméleti bérleti dijával azonosítják, ${ }^{11}$ mely elméleti bérleti díjat Hicks (1942: 176. o.) „kvázi bérleti díj”-nak nevez. Az elméleti bérleti díjban a szolgálatok használóinak értékítélete tükröződik, ezáltal biztosítja az eszközérték vállalat független ${ }^{12}$ meghatározását.

Követve Hulten (1990), valamint Diewert és Wykoff (2006) gondolatmenetét, egy $[s=0,1,2 \ldots S]$ éves eszköz egy periódusra vonatkozó szolgálatának értékét jelöljük a $t$ idópontban $\mathrm{P}_{\mathrm{t}, \mathrm{s}}^{\mathrm{K}}-\mathrm{el}$. Ekkor az $s$ éves eszköz $t$ idôpontra ${ }^{13}$ vonatkozó $\mathrm{P}_{\mathrm{t}, \mathrm{s}}^{\mathrm{I}}$ állományértékét a jövő́beni szolgálatainak nettó jelenértékeként a következóképpen számíthatjuk.

$$
\text { (4) } P_{t, s}^{I}=\sum_{\tau=0}^{S-s} P_{t+\tau, s+\tau}^{K} /\left(1+r_{t}\right)^{\tau}
$$

Ahol $S$ az eszköz múködési élettartamának végét, az $\mathrm{r}_{\mathrm{t}}$ pedig a diszkontáláshoz használt konstans kamatrátát jelöli az egyes jövő́beni periódusokban.

\section{Az eszközök értékváltozását előidézô jelensé- gek megragadása a tốkeévjárat-modellben}

A használata, valamint a gazdasági környezetben lévő technológiai fejlődés következtében a használatban lévő eszközök értéke az idő elôrehaladtával folyamatosan csökken. A csökkenés okát Griliches (1963) az eszközök kimerülésében, elhasználódásában és avulásában látta. Griliches szerint a kimerülése az eszköz értékcsökkenésének azon 
része, amely az eszköz várható múködési élettartamának csökkenéséból ered, azaz abból, hogy az eszköz várható múködési élettartama eggyel kevesebb lesz a periódus végén, mint amennyi volt a periódus elején. Ezzel szemben az elhasználódást az eszköz életkorának növekedéséból származó produktivitás vesztésnek tekintette, amely ez esetben azt jelenti, hogy az eszköz produktív szolgálatai a kor növekedésével egyre csökkennek az egyes jövőbeni periódusokban. Az elhasználódást Triplett (1996) további két tényezővel, a romlással, valamint az eszközök tönkremenetelével magyarázza, mely tönkremenetel azonban csak egy eszközcsoport vizsgálata esetén értelmezhetô. Triplett (1996) romlásnak tekinti azt a jelenséget, amikor az eszköz korának növekedésével az eszköz produktív hatékonysága csökken, azaz a kor előrehaladtával az eszköz egyre „gyengébb”, vagy „szegényebb” szolgálatot képes nyújtani. A romlás jelensége azonban vizsgálható input és output oldalról is. A megkülönböztetést először Feldstein és Rothschild (1974) tette. Az inputromlás értelmezésükben azt jelenti, hogy egy eszköz az életkorának növekedésével azonos szolgálatok kifejtéséhez egyre több múködési input szükséges, mint fiatalabb korában, ezzel szemben az outputromlást úgy határozták meg, hogy az eszköz a korának növekedésével egyre kevesebb produktív szolgálatot képes nyújtani az egyes periódusokban, mint fiatalabb korában. Tehát az eszközök bizonyos körének produktív hatékonysága a fenti hatások miatt az életkor növekedésével egyre csökken.

Az eszközök produktív hatékonyságának ismeretében az egymást tökéletesen helyettesítő, de különböző hatékonyságú eszközök hatékonysági súlyok alkalmazásával egymásból kifejezhetốk. Az egyszerúsítő felismerés Christensen és Jorgenson (1973) munkájában jelent meg elsôként, s melyet azóta eszközévjárat- vagy tókeévjárat-modellnek neveznek az irodalomban. A tókeévjárat-modell alapgondolata, hogy az idősebb eszköz a produktív hatékonyságának csökkenése miatt kevésbé értékes szolgálatot képes nyújtani, mint egy fiatalabb példány, tehát egymást tökéletesen helyettesító, de különböző életkorú eszközök esetében az idősebb példány szolgálatértéke az új eszköz szolgálatának értékéből relatív hatékonysági súly használatával kifejezhetô. Ebbool következóen az eszközök bérleti piacán, versenypiaci körülményeket feltételezve a következó kifejezés igaznak tekinthető (Diewert - Wykoff, 2006):

$$
\text { (5) } \mathrm{P}_{\mathrm{t}, \mathrm{s}}^{\mathrm{K}}=\varphi_{\mathrm{s}} \mathrm{P}_{\mathrm{t}, 0}^{\mathrm{K}}
$$

Ahol $\phi_{\mathrm{s}}$ az s korú eszköz relatív hatékonyságát fejezi ki egy új eszköz $\phi_{0}=1$ hatékonyságához képest. Ekkor az (5)-ös kifejezés felhasználásával a (4)-es egyenlet a következóképpen írható fel:

$$
\text { (6) } \mathrm{P}_{\mathrm{t}, \mathrm{s}}^{\mathrm{I}}=\sum_{\tau=0}^{\mathrm{S}-\mathrm{s}} \varphi_{\mathrm{s}+\tau} \mathrm{P}_{\mathrm{t}+\tau, 0}^{\mathrm{K}} /\left(1+\mathrm{r}_{\mathrm{t}}\right)^{\tau}
$$

Tehát a (6)-os egyenlet jobb oldalán az egyes korú eszközhöz tartozó $\mathrm{P}_{\mathrm{t}, \mathrm{s}}^{\mathrm{K}}$ szolgálatértéket az új $s=0$ eszközök $t$ idôpontbeli szolgálatainak $P_{t+\tau, 0}^{K}$ értékébôl a $\phi_{\mathrm{s}}$ relatív hatékonysági súlyok használatával határozhatók meg. Amennyiben azt feltételezzük, hogy a gazdasági környezetben nincs technológiai fejlődés, úgy az eszköz szolgálatának hatékonyságcsökkenését az eszköz elhasználódása okozza, melyet nagymértékben befolyásol az eszköz használatának mértéke, jellege, valamint az eszköz minősége, mely jellemzők alapján meghatározott $\phi_{\mathrm{s}}$ hatékonysági súlyokat és az általuk kirajzolt hatékonyságcsökkenési profilt (mintát) stabilnak tételezzük fel minden jövőbeni $t+\tau$ periódusban.

Az eszközök alapvetố tulajdonságai, valamint változatos használati módja és minôsége alapján a szakirodalom három jellemző hatékonysági mintát - konstans, lineáris és mérta$n i$ - különböztet meg egymástól a hatékonyságok kor szerinti lefutására vonatkozóan, mely mintákat Hulten (1990) és Hulten és Wykoff (1996) részletesen ismertetik. A konstans, lineáris és mértani hatékonyságvesztési mintákat a 2. ábra szemlélteti.

\section{A különbözố eszközhatékonysági minták az eszköz} korának függvényében

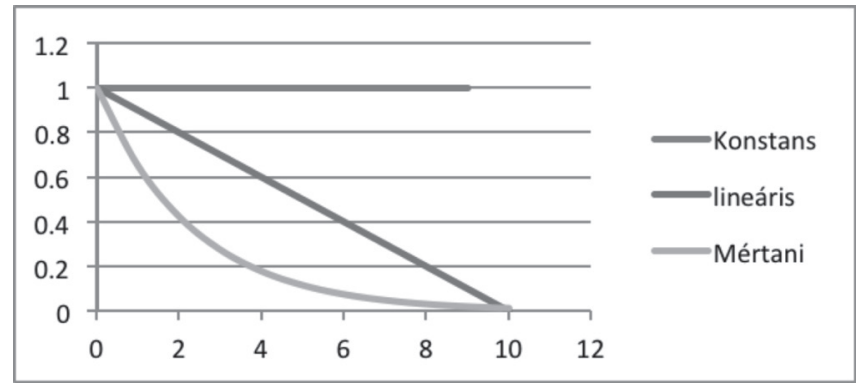

A 2. ábrán látható hatékonyságcsökkenési minták a (6)os egyenletben vázolt összefüggés alapján azonban hatással vannak az eszköz értékeire, melynek kor szerinti lefutását az árak stabilitása és $\mathrm{r}_{\mathrm{t}}=0,1$ esetén a 3. ábra szemléltet. ${ }^{14}$

3. ábra

A különbözố hatékonysági minták által eredményezett eszközérték lefutások

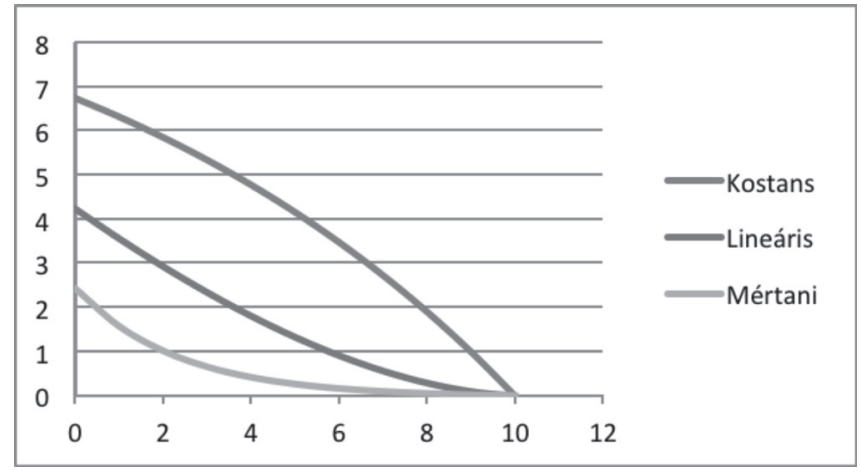

\section{VEZETÉSTUDOMÁNY}


Az eszközérték változására ható másik jelenségcsoport a Griliches (1963) által említett avulás, melyet úgy határoz meg, hogy a technikai fejlődés következtében a régebbi technológiát képviselő eszközök szolgálatai kevésbé lesznek értékesek, mint az új technológiát használó eszközöké, azaz csökken az eszköz produktivitásának relatív piaci megtérülése, melyet az egyéb relatív árváltozások is befolyásolnak. Az iménti meghatározás elsố részében Griliches az új technológiát tartalmazó eszköz megjelenésével, míg a második részében a relatív árváltozásokkal magyarázza az avulás jelenségét. Ez a látszólagos eltérés azonban mindkét esetben a technológiai fejlódésre vezethetô vissza, mely azonban különbözó formákban jelenhet meg a gazdaságban. Ezt a technológiai fejlődést Jorgenson (1966) és Hall (1968) két jól elkülönülő részre, testet öltő és testet nem öltố technológiai fejlödésre bontja. A testet öltố technológiai fejlódés esetén az eszköz egy újabb, fejlettebb példánya jön létre, míg a testet nem öltố technológiai fejlódés esetén más technológiák általános fejlődésének hatására az adott eszköz szolgálatai elértéktelenednek, azaz az eszköz cserearánya megváltozik. Griliches, Jorgenson és Hall felismerésére építve Diewert és Wykoff (2006) a technológiai fejlődés fenti megkülönböztetése alapján testet öltő és testet nem öltó avulást különít el egymástól. Testet öltő avulásnak azt tekintik, amikor egy újabb, fejlettebb eszköz megjelenésének hatására a régebbi technológiát tartalmazó eszköz értéke csökken, míg testet nem öltó avulásnak tekintik, amikor a piacon nem jelenik meg újabb, fejlettebb eszköz, viszont az eszköz szolgálatának értéke idôról idôre csökken a piaci kereslet csökkenése, vagy más eszközök fejlődése miatt.

Az avulás eszközértékre gyakorolt hatásának vizsgálatához azonban szükség van a (6)-os egyenletben bemutatott tókeévjárat-modell kibóvítésére. Diewert és Wykoff (2006) gondolatmenetét követve különbséget teszek a vizsgált $t$ idôpontban megfigyelhető szolgálatértékek, és az egyes jövốbeni periódusok elején várt szolgálatértékektôl az azonos korú eszközök esetében. Azt feltételezem tehát, hogy az azonos korú eszközök szolgálatértékei között az egyes $t$ idôpontokban a következó összefüggés áll fenn:

$$
\text { (7) } \begin{aligned}
& P_{t, s}^{K} *\left(1+i_{t, 0}\right)=P_{t, s}^{K} ; P_{t, s}^{K} *\left(1+i_{t, 1}\right)= \\
& P_{t+1, s}^{K} ; P_{t, s}^{K} *\left(1+i_{t, 1}\right)\left(1+i_{t, 2}\right)=P_{t+2, s}^{K} ; \ldots
\end{aligned}
$$

Ahol az $1+\mathrm{i}_{\mathrm{t}, \tau}$ a szolgálat értékének változási faktora, mely az eszköz szolgálatértékének jövőbeni $[\tau=1,2,3$...] várható változását fejezi ki a $t$ idôpontban becsülve, az eszköz jellemzőinek (elhasználtság és testet öltő avulás) változásától függetlenül. Másként megközelítve, az $1+\mathrm{i}_{\mathrm{t}, \mathrm{\tau}}$ faktor az eszköz egységnyi szolgálatának $t$ idópontban becsült nominál árváltozását fejezi ki egyik jövóbeni $\tau$ idốpontról a következó $\tau+1$ idôpontra vonatkozóan.

Az egyszerúbb kezelhetőség érdekében Diewert és Wykoff (2006) feltételezi, hogy az eszközök egységnyi szolgálatának árát befolyásoló $i_{t, \tau}$ ráta a vizsgált jövőbeni $\tau=1,2,3 \ldots$ periódusokban egyenlők, azaz:

$$
\text { (8) } i_{t, \tau}=i_{t} ; \tau=1,2,3, \ldots
$$

Ekkor a (6)-os egyenlet, amely az eszköz $t$ idôpontban számított $\mathrm{P}_{\mathrm{t}, \mathrm{s}}^{\mathrm{I}}$ értékét kapcsolja össze a jövőbeni szolgálatok $\mathrm{P}_{\mathrm{t}, \mathrm{s}}^{\mathrm{K}}$ értékével, a (7)-es és (8)-as kifejezések felhasználásával a következőképpen írható fel:

$$
\text { (9) } P_{t, s}^{I}=\sum_{\tau=0}^{S-S}\left(1+i_{t}\right)^{\tau} \varphi_{s+\tau} P_{t, 0}^{K} /\left(1+r_{t}\right)^{\tau}
$$

A (9)-es egyenlet jobb oldalán a különböző $s$ korú eszközök elhasználódását kifejezố $t$ időpontban érvényes $\varphi_{s+\tau} P_{t, 0}^{K}$ szolgálatértékeit tehát az $\left(1+\mathrm{i}_{\mathrm{t}}{ }^{\tau}\right.$ faktor segítségével számítjuk a $t+\tau$ idópontban érvényes szolgálatértékké, azaz

$$
\text { (10) }\left(1+i_{t}\right)^{\tau} \varphi_{s+\tau} P_{t, 0}^{K}=P_{t+\tau, s+\tau}^{K} ; \tau=0,1,2, \ldots
$$

Ahol $\tau=0$ esetén $\left(1+\mathrm{i}_{\mathrm{t}}\right)^{\tau}=1$.

\section{A testet nem öltő technológiai fejlôdés és avulás}

A testet nem öltő technológiai fejlődés viszont egy olyan feltételezett technológiai fejlődés, amely nem az adott szolgálatot előállító eszköz fejlettebb példányában „ölt testet”, hanem az eltérô szolgálatot nyújtó eszközök esetében jelentkezik, melynek eredményeképp a vizsgált eszköz szolgálata iránti kereslet csökken. Ennek következménye, hogy az eszköz szolgálatának $\mathrm{P}_{\mathrm{t}, \mathrm{s}}^{\mathrm{K}}$ értéke szintén csökken. ${ }^{15}$ Amennyiben a szolgálatérték csökkenése a jövốben előre látható, úgy a (9)-es egyenletben meghatározott összefüggés alapján maga az eszköz $\mathrm{P}_{\mathrm{t}, \mathrm{s}}^{\mathrm{I}}$ értéke is csökken. ${ }^{16}$

A (7)-es egyenlet kapcsán meghatároztuk a szolgálatok $\mathrm{P}_{\mathrm{t}, \mathrm{s}}^{\mathrm{K}}$ értékének $t$ idôpontban becsült, jövốbeni $\mathrm{t}+\tau$ periódusokra érvényes $1+i_{t, \tau}$ eszközspecifikus nominális árváltozási tényezőjét, melyrő́l a (8)-as kifejezés kapcsán a modell átláthatósága érdekében azt feltételeztük, hogy értéke minden jövőbeni $\mathrm{t}+\tau$ periódusban konstans. Diewert és Wykoff (2006) a $t$ idôpontban becsült $i_{t}^{*}$ nominál eszközspecifikus árszínvonal-változást két részre, $\rho_{\mathrm{t}}$ általános árszínvonal- 
változásra, ${ }^{17}$ valamint $i_{t}{ }^{*}$ eszközspecifikus reál árszínvonalváltozásra bontja, melyek kapcsolatát a következő kifejezés szemlélteti:

$$
\text { (11) } 1+i_{t}^{*}=\frac{1+i_{t}}{1+\rho_{t}}
$$

Diewert és Wykoff (2006) gondolatmenetét követve a $\rho_{\text {t }}$ általános árszínvonal-változás azonban nem csak a szolgálatértékekre van hatással, hanem a (4)-es kifejezés kapcsán meghatározott $r_{t}$ nominál kamatrátára is, mely szintén két részre, $\rho_{\mathrm{t}}$ általános árszínvonal-változásra, valamint $r_{\mathrm{t}}^{*}$ reál kamatrátára bontható, azaz

$$
\text { (12) } 1+r_{t}^{*}=\frac{1+r_{t}}{1+\rho_{t}}
$$

Amennyiben a (11)-es és (12)-es összefüggésekból kifejezett nominál rátákat a (9)-es egyenletbe helyettesítjük, akkor a jobboldali kifejezés egyszerúsíthetô a $1+\rho_{\mathrm{t}}$ átlagos árszínvonal-változási faktorral. Ekkor az eszközérték következő meghatározásához jutunk:

$$
\text { (13) } P_{t, s}^{I}=\sum_{\tau=0}^{S-S}\left(1+i_{t}^{*}\right)^{\tau} \varphi_{s+\tau} P_{t, 0}^{K} /\left(1+r_{t}^{*}\right)^{\tau}
$$

Tehát az eszközértéket a modell szerint a feltételezett

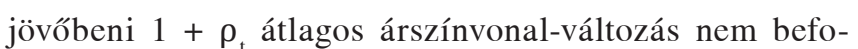
lyásolja.

Amennyiben az eszköz szolgálatának jövőbeni értéke a testet nem öltố technológiai fejlódés miatt csökken, úgy az imént meghatározott $i_{t}^{*}$ eszközspecifikus reál árszínvonal-változási ráta negatív lesz, amely egy $t$ idôponttól kezdődôen az eszköz teljes élettartamára vonatkozóan megjelenik. Tehát a testet nem öltố technológiai fejlödés hatására fellépô testet nem öltố avulás a szolgálatok $\mathrm{P}_{\mathrm{t}, \mathrm{s}}^{\mathrm{K}}$ értékének a jövő́beni periódusok szerint vizsgált függvényét „lejjebb” tolja, mely elmozdulást a 4. ábra szemléltet.

4. ábra

Az avulatlan és a testet nem öltő avulással módosított szolgálatértékek alakulása a jövốbeni periódusokban

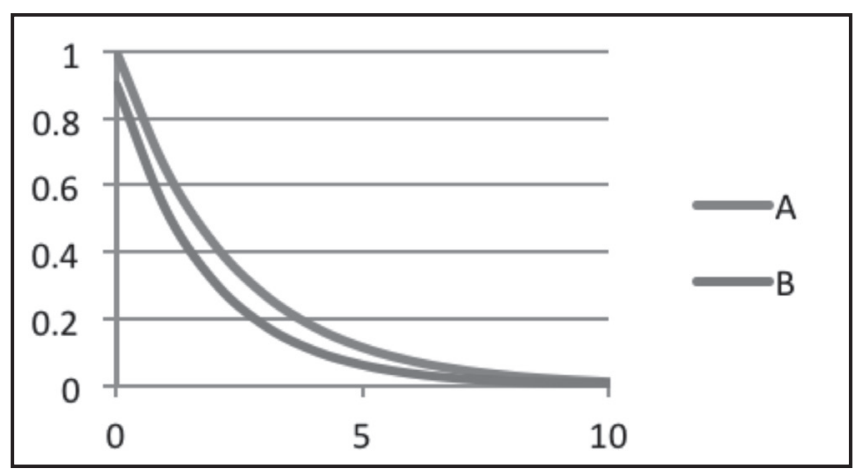

A 4. ábrán „A"-val jelöltem a $\mathrm{P}_{\mathrm{t}, \mathrm{s}}^{\mathrm{K}}$ szolgálatértékek eredeti, „,avulatlan” függvényét a jövőbeni periódusokban, mely függvény meghatározása során 10 éves múködési élettartamot és mértani elhasználódási mintát feltételeztem. A „B”vel jelölt függvény ezzel szemben az „A" függvény $\mathrm{i}_{\mathrm{t}}{ }^{*}=-0,1$ eszközspecifikus reál árváltozási rátával módosított változatát mutatja. Tehát jól látszik, hogy a testet nem öltó avulás hatására az eszköz szolgálatának értéke a jelen és minden jövóbeni periódusban csökken.

A $\mathrm{P}_{\mathrm{t}, \mathrm{S}}^{\mathrm{K}}$ szolgálatértékekre ható teste nem öltố avulás a (13)as kifejezésben meghatározott összefüggés szerint magára az eszköz értékére is hatással van, mely hatást az 5. ábra szemléltet.

Az avulatlan és a testet nem öltố avulással módosított eszközértékek alakulása a jövóbeni periódusokban

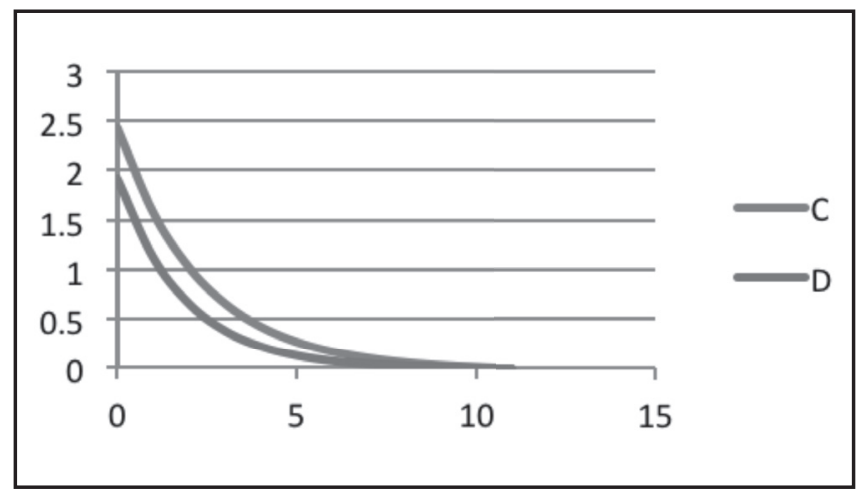

A 4. ábrán előzőekben „A”-val jelölt szolgálatértékekből $\mathrm{r}_{\mathrm{t}}^{*}=0,1$ reál kamatrátával számolt $\mathrm{P}_{\mathrm{t}, \mathrm{s}}^{\mathrm{I}}$ eszközértékek függvényét az 5. ábrán „C”-vel, míg az elôzóekben „B”-vel jelölt szolgálatértékekből szintén $r_{t}^{*}=0,1$ reál kamatrátával számolt $\mathrm{P}_{\mathrm{t}, \mathrm{s}}^{\mathrm{I}}$ eszközértékek függvényét „,D”-vel jelölöm.

A 4. és az 5. ábra esetében is látható tehát, hogy a becsült testet nem öltố avulás hatással van az eszköz szolgálatának jövóbeni értékeire, melyen keresztül magát az eszköz értékének lefutását is befolyásolja.

\section{A testet öltő technológiai fejlődés és avulás}

Az elóbbiekben tárgyalt jelenséggel szemben testet öltó technológiai fejlódésnek tekintjük azt, amikor egy újabb, magasabb technológiai színvonalú, de azonos szolgálatot nyújtó helyettesítő eszköz jelenik meg a piacon. A magasabb technológiai fejlettség az eszköz esetében hosszabb élettartamban, illetve produktív hatékonyságának javulásában mutatkozhat meg. A fejlettebb eszköz élettartamá-

\section{VEZETÉSTUDOMÁNY}


nak növekedése és termelési hatékonyságának javulása a korábban meghatározott kimerülés és elhasználódás ellentétének is tekinthetô. Amennyiben egy fejlettebb eszköz várható élettartama magasabb, mint egy fejletlenebbé, akkor a fejlettebb eszköz kimerülése hosszabb idő alatt megy végbe, mint egy fejletlenebbé, amely csak akkor befolyásolja a fejletlenebb eszköz szolgálatának $\mathrm{P}_{\mathrm{t}, \mathrm{s}}^{\mathrm{K}}$ értékét, ha az eszköz múködtetéséhez telepítési, installálási költség is kapcsolódik. Ekkor ugyanis a telepítési és installációs költségek többször merülnek fel egy fejletlenebb eszköz esetében, mely költségtöbblet csökkentheti a fejletlenebb eszköz szolgálatainak $\mathrm{P}_{\mathrm{t}, \mathrm{s}}^{\mathrm{K}}$ értékét, amelyet korábban az eszköz elméleti bérleti díjával azonosítottunk.

A produktív hatékonyság javulása a romlás analógiájára input és output oldalról is értelmezhetô. Az outputhatékonyság-javulás ez esetben azt jelenti, hogy az eszköz az elkövetkezô periódusokban azonos inputfelhasználás mellett több outputot képes előállítani, mint egy fejletlenebb eszköz. ${ }^{18}$ Ezzel szemben az inputhatékonyság-javulás azt jelenti, hogy az eszköz azonos mennyiségú output kibocsátása esetén kevesebb inputot használ. ${ }^{19} \mathrm{~A}$ technológiai fejlődés hatására létrejövố hatékonyságjavulás következtében tehát a fejletlenebb eszközök szolgálatainak $\mathrm{P}_{\mathrm{t}, \mathrm{s}}^{\mathrm{K}}$ értéke csökken a fejlettebb eszköz használata által biztosított elônyök miatt, mely hatás a fejletlenebb eszköz $\varphi_{\mathrm{s}}$ relatív hatékonyságcsökkenésében jelenik meg. Mivel az új eszköz szolgálatának értékét a testet öltő technológiai fejlődés nem befolyásolja, ezért a (11)-es kifejezésben meghatározott $i^{*}{ }_{t+1}$ reál árszínvonal-változási ráta minden jövóbeni periódusban $i_{\mathrm{t}}^{*}=0$. A hatékonyságjavulásban és az élettartam-növekedésben testet öltô technológiai fejlődés által előidézett csökkenést a fejletlenebb eszközök $\mathrm{P}_{\mathrm{t}, \mathrm{s}}^{\mathrm{I}}$ értékében ez alapján testet öltó avulásnak nevezzük.

Ekkor az (5)-ös kifejezésben meghatározott hatékonysági súlyok már nemcsak az elhasználódás hatásait tartalmazzák, hanem a testet öltố avulásét is. Tehát testet öltô technológiai fejlődés esetén egy $s$ korú eszköz hatékonysága nemcsak elhasználódás miatt kisebb, mint egy új eszközé, hanem azért is, mert az új eszköz hatékonysága az $s$ korú eszköz $s$ periódussal ezelőtti hatékonyságát is meghaladja, azaz az s korú eszköz új korában tekintett produktív hatékonyságát.

A testet öltô technológiai fejlődés által elóidézett avulás az eszköz szolgálatának $\mathrm{P}_{\mathrm{t}, \mathrm{s}}^{\mathrm{K}}$ értékét tehát az elhasználódás hatásain túl is csökkenti az eszköz korának elôrehaladtával, ezáltal a szolgálatérték kor szerinti függvénye meredekebbé válik, mely hatást a 6 . ábra szemléltet.
6. ábra

Az avulatlan és a testet öltố avulással módosított szolgálatértékek alakulása a jövoóbeni periódusokban

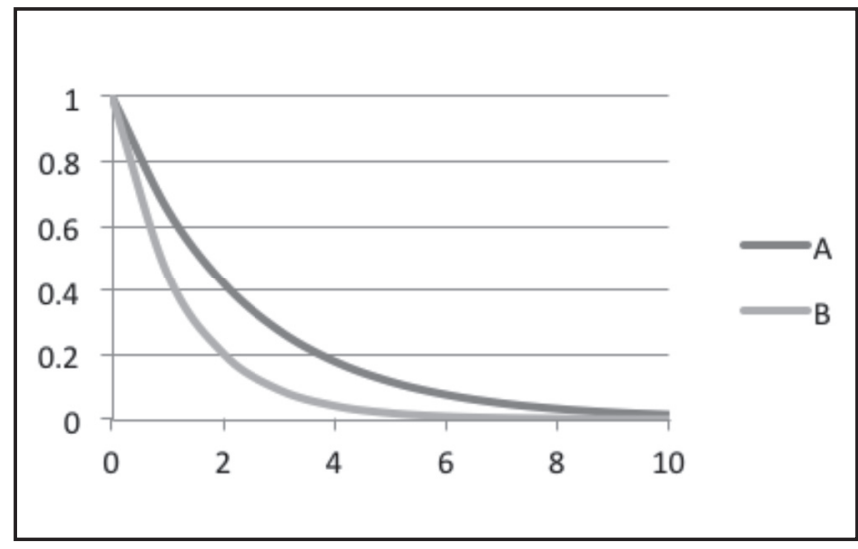

A 6. ábrán „A”-val jelöltem a $\mathrm{P}_{\mathrm{t}, \mathrm{s}}^{\mathrm{K}}$ szolgálatértékek eredeti, avulatlan kor szerinti függvényét, mely függvény meghatározása során 10 éves múködési élettartamot és mértani elhasználódási mintát feltételeztem. A „B”-vel jelölt függvény ezzel szemben az „A” függvény testet öltő avulással módosított változata, mely esetében az elhasználódást kifejezô hatékonyságcsökkenési rátát a feltételezett testet öltó avulás következtében fellépő relatív hatékonyságcsökkenéssel növeltem. A 6. ábrából jól látszik, hogy a testet öltố avulás hatására az eszköz szolgálatának értéke minden jövóbeni periódusban csökken, azonban a jelen periódusban érvényes újeszköz szolgálatértékét nem befolyásolja.

A $\mathrm{P}_{\mathrm{t}, \mathrm{s}}^{\mathrm{K}}$ szolgálatértékekre ható avulás a (13)-as kifejezésben meghatározott összefüggés alapján azonban nem csak a szolgálatértékre, hanem magára az eszköz értékére is hatással van, mely hatást a 7. ábra szemléltet.

\section{7. ábra}

Az avulatlan és a testet öltố avulással módosított eszközérték alakulása a jövôbeni periódusokban

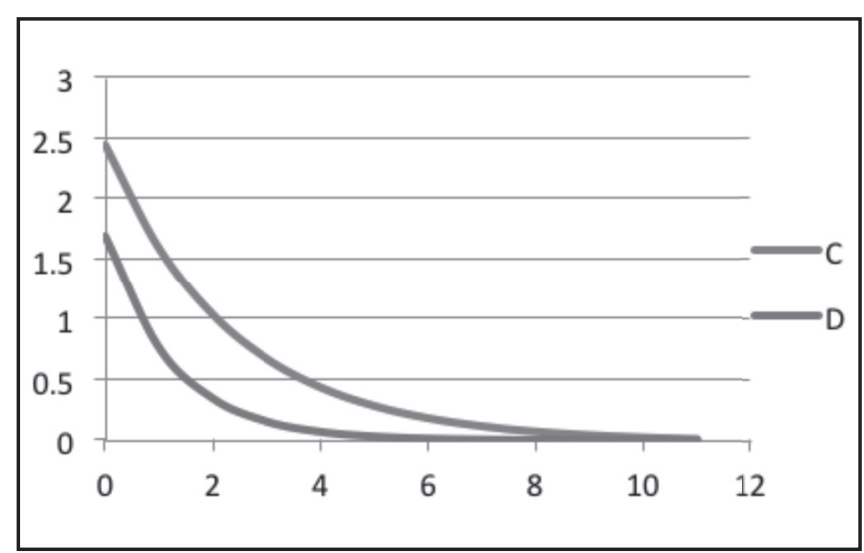


A 7. ábrán „C”-vel jelöltem a 6. ábra „A” függvénye által meghatározott szolgálatértékekből $\mathrm{r}_{\mathrm{t}}^{*}=0,1$ reál kamatrátával számolt $\mathrm{P}_{\mathrm{t}, \mathrm{s}}^{\mathrm{I}}$ eszközértékek függvényét, míg „,D”vel jelöltem a 6. ábra „B” függvénye által meghatározott szolgálatértékekból szintén $\mathrm{r}_{\mathrm{t}}^{*}=0,1$ reál kamatrátával számolt $\mathrm{P}_{\mathrm{t}, \mathrm{s}}^{\mathrm{I}}$ eszközértékek függvényét.

A 6. és 7. ábrából látható tehát, hogy a becsült testet öltő avulás hatással van az eszköz szolgálatának jövőbeni értékeire, melyen keresztül magát az eszköz értékének lefutását is befolyásolja.

\section{Összegzés}

A cikkben ismertetett kimerülés, elhasználódás és testet öltố avulás jelenségek tehát hatással vannak az eszközök $t$ idốpontban mért, az eszköz korának növekedéséből fakadó értékváltozására, mely értékváltozást a (2)-es egyenletben $D_{t, s}$ keresztmetszeti értékcsökkenésnek neveztünk. Ez az értékcsökkenés a (2)-es és a (13)-as kifejezések felhasználásával a kövező formában írható fel:

$$
\begin{aligned}
& \text { (14) } D_{t, s}=P_{t, s}^{I}-P_{t, s+1}^{I}= \\
& \sum_{\tau=0}^{S-S} \frac{\left(1+i_{t}^{*}\right)^{\tau} \varphi_{S+\tau} P_{t, 0}^{K}}{\left(1+r_{t}^{*}\right)^{\tau}}-\sum_{\tau=0}^{S-(s+1)} \frac{\left(1+i_{t}^{*}\right)^{\tau} \varphi_{s+\tau+1} P_{t, 0}^{K}}{\left(1+r_{t}^{*}\right)^{\tau}}
\end{aligned}
$$

Mely keresztmetszeti értékcsökkenés az árak stabilitása $i_{t+1}^{*}=0$ esetén, valamint a jövoóre vonatkozó pontos ismerete és bizonyosság esetén megegyezik az eszköz (1)-es egyenletben meghatározott értékváltozásával.

A $D_{t, s}$ keresztmetszeti értékcsökkenés elsôként tárgyalt összetevôje a kimerülés, mely következtében egy $s+l$ korú eszköz egyel kevesebb jövőbeni múködési periódussal rendelkezik, mint egy $s$ éves eszköz, ezáltal azt mondhatjuk, hogy az eszköz korának növekedésével egyre kimerültebbé válik, mely kimerülés hatása természetesen az eszköz $\mathrm{D}_{\mathrm{t}, \mathrm{s}}$ értékcsökkenésében is jelentkezik, azaz $\mathrm{S}-\mathrm{S}>$ $\mathrm{S}-(\mathrm{s}+1)$.

Azonban az eszköz korának növekedésével nemcsak a hátralévő múködési periódusai csökkennek, hanem az egyes hátralévő periódusokban kifejtett szolgálatainak relatív hatékonysága is, mely relatív hatékonyságot az eszköz elhasználódása, valamint a testet öltő avulás befolyásol. Tehát az eszközök életkorának növekedésével egyre szegényebb szolgálatokat képesek nyújtani, melyet nem kizárólag a fizikai elhasználódásuk okoz, hanem az újabb, fejlettebb eszközök megjelenése, melynek következtében a régebbi technológiát tartalmazó eszközök szolgálatai egvre értéktelenebbé, avultabbá válnak, mely hatásokat a $\varphi_{s+\tau}$ hatékonysági súlyok fejeznek ki. Ezáltal azt mondhatjuk, hogy az elhasználódás és a testet öltó avulás hatására egy $s+1$ korú eszköz szolgálatának értékéhez kiesebb hatékonysági súly tartozik, mint egy $s$ korú eszközéhez, azaz $\varphi_{S}>\varphi_{S+1}$, tehát az elhasználódás és a testet öltô avulás hatásai megjelennek a (14)-es egyenletben meghatározott $D_{t, s}$ keresztmetszeti értékcsökkenésben, mely keresztmetszeti értékcsökkenés része az eszköz idősor értékcsökkenésének.

A testet nem öltố avulás jelensége a (11)-es egyenletben meghatározott $i_{\mathrm{t}}^{*}$ reál árszínvonal-változási rátán keresztül befolyásolja az eszközök hátralévő periódusainak szolgálatértékeit. Ekkor azonban a jövőre vonatkozó tökéletes informáltság feltételezése mellett ${ }^{20}$ a keresztmetszeti értékcsökkenés már eltér az (1)-es egyenletben meghatározott értékváltozástól, azaz az idősor értékcsökkenéstől, melyet a következóképpen határozhatunk meg. ${ }^{21}$

$$
\begin{aligned}
& \text { (15) } \Delta P_{t, s}^{I}=P_{t, s}^{I}-P_{t+1, s+1}^{I}= \\
& \sum_{\tau=0}^{S-S} \frac{\left(1+i_{t}^{*}\right)^{\tau} \varphi_{s+\tau} P_{t, 0}^{K}}{\left(1+r_{t}^{*}\right)^{\tau}}-\sum_{\tau=0}^{S-(s+1)} \frac{\left(1+i_{t}^{*}\right)^{\tau} \varphi_{s+\tau+1} P_{t, 0}^{K}\left(1+i_{t}^{*}\right)}{\left(1+r_{t}^{*}\right)^{\tau}}
\end{aligned}
$$

Ahol az infláció hatásától eltekintve $P_{+n}^{K}\left(1+i_{t}^{*}\right)=P_{t+1.0}^{K}$. Ezáltal a testet nem öltố avulás hatásai a $P_{t+1, s+1}^{I}$ eszközérték esetében nem csak a jövóbeni $t+1+\tau$ periódusok szolgálatértékeit, hanem a $\mathrm{t}+1$ periódus szolgálatértékét is módosítják, így hatással van az eszköz idősor-értékcsökkenésére.

A tartós eszközök idösor-értékcsökkenésének pontos meghatározásához tehát szükséges a kimerülés, elhasználódás jelenségeken túl a testet öltố és testet nem öltő avulás hatásainak figyelembevétele, melynek mikéntje az értékcsökkenés jövedelmi és egységköltség funkcióin keresztül hatással van a vállalkozás termék- és tókepiaci versenyképességére.

\section{Lábjegyzet}

1 Az eszközök felemésztődése felőli közelítés a Nemzetközi Pénzügyi Beszámolási Standardokban (IFRS) is megjelenik. Az IAS 16 standard 60-as bekezdése értelmében az eszköz értékcsökkenését úgy kell elvégezni, hogy az viszszatükrözze az eszközból származó jövő́beni hasznok elfogyasztásának mintáját.

2 A tôke megốrzésének koncepcióit lásd bővebben: Bélyácz (1994a).

3 Például költségallokációs és pótlási alap közelítés. lásd bôvebben: Bélyácz (1993).

$4 \mathrm{Az}$ értékcsökkenés költség- és értéktermészetérôl lásd bôvebben: Bélyácz (1994b).

5 Lásd például: Hulten és Wykoff (1981b) és (1996),

\section{VEZETÉSTUDOMÁNY}


Jorgenson (1996) Diewert (1996), Triplett (1996), Wykoff (2003), Diewert és Wykoff (2006).

6 Mely megfelel a Hotelling által definiált értékcsökkenésnek.

7 A nemzetközi szakirodalomban a dátumhatást gyakran időhatásnak nevezik, mely azonban zavarokat okozhat az által, hogy a korhatás értelmezésében is megjelenik az idó dimenzió.

8 Lásd többek közt: Hulten és Wykoff (1981b), Hulten (1990), Diewert (1996), Diewert és Wykoff (2006), Wykoff (2003).

9 A dátumhatás például a különbség egy 3 éves eszköz 2000. december 31-i értéke és egy ugyancsak 3 éves eszköz 2001. december 31-i értéke között, míg a korhatás például a különbség egy 3 éves eszköz 2001. december 31-i értéke és egy 4 éves eszköz 2001. december 31-i értéke között.

10 A megközelítés a számviteli gyakorlatban szintén megjelenik. Az IFRS rendszerében lévő IAS 16 standard 49-es és 50-es bekezdése egyértelmúen megfogalmazza, hogy a tartós eszközökre a jövóbeni potenciális hasznok tárházaként tekint, melynek elfogyasztása a vállalkozás múködésében hasznosul.

11 Az eszköz szolgálatértékének meghatározására kissé eltérô közelítési is létezik a szakirodalomban. Lutz, Haavelmo, Jorgenson és követôi a szolgálatok értékére úgy tekintenek, mint az $s$ éves eszköz adott periódusra vonatkozó ex post használati költségére, amely Hulten és Wykoff (1996) szerint olyan haszonáldozati költség, melyrôl a tulajdonosok akkor mondanak le, amikor saját eszközük bérbeadása mellett döntenek, azok használata helyett.

12 És egyben biztosítja a vállalat egyéb „látens” eszközeitől való független értékmeghatározását, mint például a folyamatos múködés értéke, vevôkör értéke stb.

13 A t egyben a t és $t+1$ idôpontok közti periódust is jelöli.

14 Mely jellemzôt Hulten és Wykoff (1996) és (1981a) korár profilnak nevez.

15 Például a korabeli ólom vízvezetékcsövek előállítására alkalmas berendezések iránti keresletet nyilván csökkentette a múanyagipar általános fejlôdése, ami lehetôvé tette a múanyag vízvezetékcsövek előállítását. Így az ólomcsöveket előállító gépek értéke a múanyagipar fejlődése következtében csökkent, mely csökkenés testet nem öltố avulásnak tekinthetô.

16 Az eszköz értékének ilyen jellegú csökkenését nagymértékben befolyásolja alternatív hasznosítási lehetôsége.

17 Az inflációs ráták gyakorlati meghatározásának lehetséges módjait és problémáit részletesen ismerteti Diewert (2005).

18 Azonos intenzitású használatot feltételezve.

19 Azonos intenzitású használatot feltételezve.

$20 \quad \mathrm{i}_{\mathrm{t}}^{*}=\mathrm{i}_{\mathrm{t}+\tau} ; \mathrm{r}_{\mathrm{t}}^{*}=\mathrm{r}_{\mathrm{t}+\tau} ; \tau=1,2,3, \ldots$

\section{Felhasznált irodalom}

Bélyácz Iván (1993): Amortizációelmélet. Janus Pannonius Egyetemi Kiadó, Pécs

Bélyácz Iván (1994a): A tőke megôrzésének koncepciói. Közgazdasági Szemle, 1994/7-8. 662-669. o.

Bélyácz Iván (1994b): Az amortizáció költség- és értéktermészetéról. Ipargazdasági Szemle, 3. sz. 51-62. o.

Böhm-Bawerk, E. V. (1891): The Positive Theory of Capital. Macmillan and Co., London

Christensen, L. R. - D. W. Jorgenson (1973): Measuring the Performance of The Private Sector of The US Economy, 1929-1969. in: Measuring Economic and Social Performance, edited by M Moss, Columbia University Press, New York, 233-351. o.

Diewert, W. E. (2005): Issues in the Measurement of Capital Services, Depreciation, Asset Price Changes and Interest Rates. in: Measuring Capital in the New Economy. C. Corrado, J. Haltiwanger and D. Sichel (eds.), University of Chicago Press, Chicago, 479-542. o

Diewert, W. E. (1996): The Measurement of Business Capital, Income and Performance. University of British Columbia, Vancouver

Diewert, W. E. - Wykoff, F. C. (2006): Depreciation, Deterioration and Obsolescence When There Is Embodied or Disembodied Technical Change; Price and Productivity Measurement Volumes 1 and 2, Erwin W. Diewert, Bert M. Balk, Dennis Fixler, Kevin J. Fox and Alice O. Nakamura (eds.), Trafford Press.

Griliches, Z. (1963): Capital Stock in Investment Functions Some problems of Concept and measurement; In Measurement in Economics, edited by Carl F. Christ, et al., Stanford University Press, Stanford, CA

Feldstein, M. S. - Rothschild, M. (1974): Towards an Economic Theory of Replacement Investment. Econometrica, május, 393-423. o.

Hall, R. E. (1968): Technical Change and Capital from the Point of View of the Dual; The Review of Economic Studies, Published by: Oxford University Press Vol. 35, No. 1, január, 35-46. o.

Hicks, J. R. (1942): Maintaining capital intact: a Further Suggestion; Economica. New Series, Vol. 9, No. 34, május, 174-179. o.

Hill, P. (1999): Capital Stocks, Capital Service and Depreciation. Paper presented at the third meeting of the Canberra Group on Capital Stock Statistics, Washington, DC

Hotelling, H. (1925): A General Mathematical Theory of Depreciation. Journal of the American Statistical Association 20, 340-353. o.

Hulten, C. R. (1990): The Measurement of Capital. in: Fifty 
Years of Economic Measurement, Studies in Income and Wealth. edited by Ernst R. Berndt and Jack E. Triplett. Chicago University Press for the National Bureau of Economic Research, Chicago, 119-52. o.

Hulten, C.R. - Wykoff, F. C. (1996): Issues in the Measurement of Economic Depreciation: Introductory Remarks. Economic Inquiry 34, 10-23. o.

Hulten, C. R. - Wykoff, F. C. (1981a) The estimation of economic depreciation using vintage asset prices: An application of the Box-Cox power transformation. Journal of Econometrics, Volume 15, Issue 3, április, 367396. o.

Hulten, C. R. - Wykoff, F. C. (1981b): The Measurement of Economic Depreciation. in: Depreciation Inflation and
The Taxation of Income From Capital. Edited by Charles R Hulten, The Urban Institute Press, Washington, DC, 81-125. o.

Jorgenson, D. W. (1996): Empirical Studies Of

Depreciation. Economic Inquiry, 34, 24-42. o.

Jorgenson, D. W. (1966):The Embodiment Hypothesis. Journal of Political Economy, Published by: The University of Chicago Press Vol. 74, No. 1, február, 1-17. o.

Triplett, J. E. (1996): Depreciation in Production Analysis and Income and Wealth Accounts Resolution of an Old Debate. Economic Inquiry, 34, 93-115. o.

Wykoff, F. C. (2003): Obsolescence in Economic Depreciation From the Point of View of The Revaluation Term. Pomona College. Unpublished Manuscript.

\section{E SZÁMUNK SZERZŐI}

Dr. Chikán Attila, egyetemi tanár, az MTA levelező tagja, Budapesti Corvinus Egyetem, Dr. Czakó Erzsébet, egyetemi docens, a Budapesti Corvinus Egyetem, Endrődi-Kovács Viktória, PhD. hallgató, Budapesti Corvinus Egyetem, Hegedüs Krisztina, PhD. hallgató, Budapesti Corvinus Egyetem, Dr. Jenei György, egyetemi tanár, Budapesti Corvinus Egyetem, Dr. Kuti Éva, főiskolai tanár, Általános Vállalkozási Főiskola, Szabó Ágnes, egyetemi tanársegéd, Budapesti Corvinus Egyetem, Dr. Demeter Krisztina, egyetemi docens, Budapesti Corvinus Egyetem, Szász Levente, PhD. hallgató, Bábes-Bolyai Tudományegyetem, Gyulavári Tamás, egyetemi adjunktus, Budapesti Corvinus Egyetem, Losonci Dávid István, egyetemi tanársegéd, Budapesti Corvinus Egyetem, Dr. Gelei Andrea, egyetemi docens, Budapesti Corvinus Egyetem, Vörösmarty Gyöngyi, egyetemi adjunktus, Budapesti Corvinus Egyetem, Esse Bálint, egyetemi tanársegéd, Budapesti Corvinus Egyetem, Zoltayné Dr. Paprika Zita, egyetemi docens, Budapesti Corvinus Egyetem, Szántó Richárd, egyetemi adjunktus, Budapesti Corvinus Egyetem, Kaliczka Nándor, PhD. hallgató, Budapesti Corvinus Egyetem

\section{VEZETÉSTUDOMÁNY}

